\title{
China's Renewable Energy Development: Policy, Industry and Business Perspectives
}

\author{
Christopher M. Dent \\ University of Leeds, c.m.dent@leeds.ac.uk
}

\begin{abstract}
China has been at the forefront of the recent global expansion of renewable energy (RE) activity. This paper examines how the country has achieved its position as the world's largest producer and exporter of RE products, and biggest power generator from renewables. More specifically, it explores the main motives driving renewable energy development in China, how this is embedded in broader new development thinking on realising 'ecological civilisation' goals, evolving government policies on strategic planning on renewables, and the complex multi-layered landscape of China's renewable energy business where various types of state-owned enterprises collaborate and compete among each other alongside a now large number of private companies, especially in equipment manufacturing.
\end{abstract}

Key words: China, ecological modernisation, low carbon development, renewable energy, stateowned enterprise, strategy industry theory

\section{Introduction}

\subsection{Background}

The rapid expansion of renewable energy (RE) in China since over the last decade is of some considerable significance for understanding current and possible future thinking on the country's economic, social and business development. Over time the Chinese government has afforded greater strategic priority to developing renewables as an energy sector and industry for three main reasons. First, China faces serious energy security challenges as burgeoning industrial-based development and rising material demands of business and society have intensified pressures on domestic energy reserves and raised dependency on foreign energy sources. China is now consequently one of the world's largest energy importers. Second, RE technologies are being promoted for important environmental and welfare imperatives. High carbon economic activity is causing acute pollution and other environmental problems in the country, correspondingly leading to adverse social welfare effects. The ability of renewables to produce cleaner energy makes them a vital part of the solution to this problem and addressing climate change risk. Third, renewable energy sectors such as solar and wind are viewed as important emerging strategic industries by the Chinese government, forming part of its push to make the country an 'innovation hub' economy as envisioned in the $12^{\text {th }}$ Five-Year Plan (2011-2015). Relatedly, renewable energy is a core element of the country's new low(er) carbon development strategies and efforts on sustainable development generally.

Renewable energy development in China should thus not be considered in isolation of broader development processes, strategies and contexts in which it is embedded. Thinking on China's renewable energy development also combines ideas from ecological modernisation and strategic industry theories. This applies to both government policy and business practice. The landscape of China's renewable energy business across different industry value-chains is characterised by dynamic entrepreneurism, inter-sectoral connections, a dense mix of state-owned enterprises 
and private sector companies, intensifying competition and fast expanding production capacity. The relationship between government and business here is a complex and complicated one, yet this is to be expected in a large fast-growing economy where the state is proactively supporting the development of dynamic industries such as wind and solar energy.

\subsection{Research Methods and Questions}

Research undertaken for this work is of a qualitative political economy nature, drawing upon various types of analytical and information sources over a two-year period from October 2011 to November 2013. The empirical work is set within a theoretical-conceptual framework later defined in this study that helps provide deeper explanations on both the causes and consequences of China's renewable energy development. The analysis addresses a number of research questions. It begins by asking what renewable energy is and why is it so important? These are the main research questions we have chosen, rather than straight hypotheses. Theoretical explanations for the rise of renewable energy are considered, and also what have been the main motives behind China's renewable energy development. It also explores whether the Chinese government is pursuing a unique renewable energy policy and strategy, and how this may be different to other countries. In addition, what different patterns of Chinese business development have occurred in the country's RE industries and what are the key issues arising in state-business relationships here? Further, what are some of the impacts that China is making globally on renewable energy business and industries?

\section{China and the Global Development of Renewable Energy}

\subsection{What is Renewable Energy and Why is it Important?}

Renewable energy is derived from replenishable natural processes, sources or phenomena, such as wind, solar, geothermal, hydropower, tidal, and biological matter. They are 'renewable' because in actual or theoretical terms they can provide inexhaustible supplies of energy to meet the needs of humankind. In contrast, fossil fuels (coal, oil, natural gas) and nuclear (based on uranium) are non-renewable because their energy sources are ultimately exhaustible. Today, we often refer to renewables in terms of their technological applications, among the most common being wind turbines, solar photovoltaic (PV) modules or panels, tidal barrages, biofuels, and so on. These can vary enormously in terms of scale, for example from small solar photovoltaic cells that generate a few watts of electricity to power electronic devices such as calculators to huge hydropower plants such as China's 22.5 gigawatt (GW) capacity Three Gorges Dam, the world's largest power station. Renewable energy is arguably the main element of a broader green energy cluster of technologies that additionally includes energy efficiency and saving, electric vehicles, fuel cells and other eco-industry sectors.

Renewable energy technologies provide critically important options for China in meeting various development challenges that lie ahead but nevertheless come with their own environmental and socio-economic costs. The most controversial of all has 
been the construction of numerous large hydroelectric dams that have caused destruction to local eco-systems and the relocation of millions of Chinese from their homes. The future development of large-scale tidal barrages could have similar adverse effects. More generally, renewable energy systems are in some way materially based, and require industrial processes to produce installation equipment. Consequently, no renewable energy technology is completely carbon neutral, or in an absolute pure sense completely 'renewable' as most of the materials on which they depend are depletable. Emissions from biomass and biofuel combustion can cause their own environmental problems. Some RE installations also require large areas of uninhabited space, such as wind farms and solar parks, presenting certain environmental, economic and spatial constraints. Notwithstanding these points, the ability of renewables to produce much cleaner and safer energy than fossil fuels or nuclear makes them essential to decarbonising economic activity, securing long-term energy futures, achieving sustainable development and tackling climate change. This is especially relevant to China given the country's closely related economic, energy and environmental challenges it faces domestically and its impacts in these areas globally.

\subsection{The Global Rise of Renewables}

Renewable energy technologies have long been used by societies and civilisations around the world. In the modern era, hydroelectric dams have long been the dominant form of renewable energy installations generating utility-scale electricity, these dating back to the late $19^{\text {th }}$ and early $20^{\text {th }}$ centuries. Although the inclusion of hydropower in the renewables category remains controversial due the adverse ecological and socio-economic effects caused by large-scale dams locally, most analysts still consider it as a valid renewable energy sector, not least because of the recent growth of small-scale hydropower which is far less impactful. Other types of modern RE technology have been developed, many of which have been scaled up into mainstream industries (e.g. wind, solar) while others have remained low-level power producers like geothermal, tidal and concentrating solar power, with some still largely experimental, such as wave energy.

It was not until the early 2000s that significant growth and development in renewables generally began as new RE technologies became gradually scaled up and approached commercialisation. Wind, solar and bioenergy deserve special mention here, and electricity generation is arguably where renewables have made the biggest impact on global energy systems. Worldwide renewable energy power capacity has risen from $931 \mathrm{GW}$ in 2005 to $1,473 \mathrm{GW}$ by 2012, which represents 26.0 percent of global total, leading in addition to a rising share of global electricity generation output from 15.6 percent to 21.7 percent. As Table 1 indicates, hydropower accounted for 16.5 percent of global electricity generation in 2012, this being around threequarters of the total renewables contribution. From 2005 to 2012, wind power installed capacity has increased from $59.0 \mathrm{GW}$ to $282.6 \mathrm{GW}$, and solar PV from $5.4 \mathrm{GW}$ to $102.1 \mathrm{GW}$, the two fastest growing RE sectors. In terms of global primary energy demand, renewables accounted for 19.0 percent of the total in 2011, with traditional biomass being the most prominent RE sector (9.3 percent) and primarily related to cooking and heating in remote areas of developing countries. 


\begin{tabular}{|c|c|c|c|c|c|c|c|c|c|c|c|}
\hline \multirow[t]{2}{*}{ Power Generation } & \multicolumn{8}{|c|}{ Installed capacity, MU } & \multirow{2}{*}{\begin{tabular}{|r|} 
Global \\
installed \\
capacity, MW \\
$(2012)$ \\
\end{tabular}} & \multirow{2}{*}{\begin{tabular}{r|} 
China \% \\
share of \\
global \\
total \\
\end{tabular}} & \multirow{2}{*}{ Sector targets } \\
\hline & 2005 & 2006 & 2007 & 2008 & 2009 & 2010 & 2011 & 2012 & & & \\
\hline Hydropower $^{1}$ & 117,390 & 130,290 & 148,230 & 172,600 & 196,290 & 216,060 & 232,980 & 248,900 & 990,000 & 25.1 & $325 \mathrm{GW}$, inc 41GW pumped storage (2015); 430GW (2020) \\
\hline Wind & 1,060 & 2,599 & 5,912 & 12,210 & 25,810 & 44,733 & 62,634 & 75,374 & 282,587 & 26.7 & $100 \mathrm{GW}$, inc. $5 \mathrm{GW}$ offshore (2015); 200GW*, inc. 30GW offshore (2020) \\
\hline Solar PV & 0 & 80 & 100 & 145 & 373 & 893 & 3,093 & 8,300 & 102,156 & 8.1 & 39GW (2015); 47GW (2020) \\
\hline Biomass & 2,000 & 2,500 & 3,000 & 3,270 & 4,600 & 5,500 & 7,000 & 8,000 & 83,000 & 9.6 & 13GW (2015); 30GW (2020) \\
\hline Geothermal & 24 & 24 & 24 & 24 & 24 & 24 & 24 & 24 & 11,700 & 0.2 & \multirow{2}{*}{ 110-120MW (2015) geothermal and tidal; 50MW ocean (2015) } \\
\hline Ocean (Tidal and Wave) & 3 & 3 & 3 & 3 & 3 & 3 & 3 & 3 & 527 & 0.6 & \\
\hline Concentrating Solar Power (CSP) & 0 & 0 & 0 & 0 & 0 & 0 & 0 & 0 & 2,550 & 0.0 & 1GW (2015); 3GW (2020) \\
\hline Renewable Energy total & 120,477 & $\begin{array}{lll}135,496 \\
\end{array}$ & 157,269 & 188,252 & 227,100 & 267,213 & 305,734 & 340,601 & $1,472,520$ & 23.1 & \multirow{3}{*}{$\begin{array}{l}\text { Non-fossil fuel (inc. nuclear): primary energy 11.4\% (2015), 15\% (2020); electricity } \\
\text { generation capacity 30\% (2015) }\end{array}$} \\
\hline$\%$ share total installed capacity & 23.0 & 22.0 & 22.0 & 23.0 & 25.0 & 26.0 & 28.5 & 29.6 & & & \\
\hline$\%$ share total power output generated & 16.0 & 15.0 & 15.0 & 17.0 & 17.0 & 18.0 & 16.0 & 20.0 & & & \\
\hline Nuclear & 6,850 & 6,850 & 8,850 & 8,850 & 9,080 & 10,820 & 12,570 & 13,800 & 364,078 & 3.8 & 40GW (2015); 58GW (2020) \\
\hline$\%$ share total installed capacity & 1.3 & 1.1 & 1.2 & 1.1 & 1.0 & 1.1 & 1.2 & 1.2 & & & \\
\hline Other Energy Production & 2005 & 2006 & 2007 & 2008 & 2009 & 2010 & 2011 & 2012 & & & \\
\hline Solar water heaters (million $\mathrm{m}^{2}$ ) & 80.0 & 90.0 & 108.0 & 136.0 & 160.0 & 185.0 & 217.4 & 257.7 & & & 400 million m2 (2015) \\
\hline Biogas users (million households) & 18.1 & 21.8 & 26.2 & 30.5 & 35.1 & 39.0 & 43.0 & & & & 50 million households (2015) \\
\hline Solid biomass (1,000 tonnes) & 0 & 0 & 30 & 1,000 & 2,000 & 3,000 & 3,500 & 6,000 & & & 10 million tonnes (2011-2015) \\
\hline Bioethanol (1,000 tonnes) & 1,020 & 1,020 & 1,290 & 1,580 & 1,720 & 1,860 & 1,900 & 2,000 & & & 4 million tonnes (2011-2015) \\
\hline \begin{tabular}{|l|} 
Biodiesel (1,000 tons) \\
\end{tabular} & 50 & 50 & 100 & 300 & 500 & 500 & 400 & 500 & & & 1 million tonnes (2011-2015) \\
\hline
\end{tabular}

Sources: BP( (2013), CNREC (2013), ENA (201), da source fijures differ for China's installed wind, solar PV and geothermal energy capacity. The author has chosen to use international sourced data from international sectoral and other organisations (GWEC, EPIA, REN21, BP) for these sectors

for international comparative reasons over Chinese national data, which is generally believed to under-estimates capacity levels. * Unofficial government target.

China has been at the forefront of this global expansion of renewable energy. For a number of years its power generation capacity has been far greater than any other nation, having almost tripled from $122 \mathrm{GW}$ in 2005 to reach $341 \mathrm{GW}$ by 2012: the next ranked countries that year were the US (164GW), Germany $(76 \mathrm{GW})$, India $(67 \mathrm{GW})$ and Japan $(59 \mathrm{GW})$. Admittedly, China's dominant position owes much to a large and still expanding hydropower programme yet even if this sector was excluded, China would still be ranked first globally with $92 \mathrm{GW}$ and the US second with $86 \mathrm{GW}$ (REN21 2013). Furthermore, China has been responsible for adding around 40 percent of new additions to global renewable energy capacity since the late $2000 \mathrm{~s}$ (REN21 2006, 2013).

\subsection{Theoretical Explanations}

Much of the academic literature examining the recent growth of renewables is located in energy science-engineering fields where development is studied from primarily a technical perspective and focused on new technological advances. Social science explanations on the subject from the relevant disciplines of political economy, business studies and sociology have tended to explain the rise of renewables from one of two main theoretical approaches, both of which situate renewable energy development in broader development contexts.

The first of these is ecological modernisation theory (EMT), which first emerged in the early 1980s (Huber 1982, Jänicke 1984). This essentially is premised on the idea that sustainable development can be achieved through continual reform, modification and adaptation of existing economic and business structures. As York and Rosa (2003) succinctly summarise: "Central to [ecological modernisation theory] EMT is the view that... industrialization, technological development, economic growth, and capitalism are not only potentially compatible with ecological sustainability but also may be key drivers of environmental reform" (pg. 274). From this perspective, renewable energy is viewed as providing technical solutions to sustainable development challenges facing humanity. Despite criticisms made of EMT for prescribing incremental rather than revolutionary change, it remains the 
dominant discourse among key decision-makers in both government and business circles regarding environment-related policies. An important reason for this is the appealing economic case it makes on how companies can increase profitability by pursuing green corporate strategies, through for instance improving material efficiency and waste management, and exploiting the emerging market potential of environmentally friendly products such as renewables (Christoff 1996, Jänicke 1988). EMT postulates that economic and business growth is reconcilable with resolving environmental problems, and firms can generate financial gains through adopting new environmental technologies and practices (Langhelle 2000, Weale 1992).

Founded on closely related theories of industrial policy, strategic trade and state capacity, strategic industry theory is the second broad social sciences approach that can explain renewable energy development. It essentially concerns the state's promotion of industries deemed essential to the nation's long-term economic security, welfare and prosperity. The theory's main premises are based on public good and externality arguments. While the market mechanism can account for the 'private' and purely price-determined costs and benefits arising from economic transactions, it can fail to capture their external 'social' costs and benefits. Public actions undertaken by the state are thus required in such circumstances to both minimise negative externalities and properly capture or optimise positive externalities. Thus, state policies and investments in renewable energy installations and technologies will reduce carbon emissions, lead to cleaner air, and mitigate society's supply risk dependency on exhaustible fossil fuel resources. These state actions constitute the provision of public goods where the market (i.e. private enterprise) alone is unable to independently and sufficiently deliver these welfareenhancing outcomes, and more broadly placing the economy and society on track to a lower carbon future. Left purely to the market, many RE sectors would not become technologically developed enough or adequately commercialised to compete on price with fossil fuel generated energy.

Strategic industry theory further makes a case for state support towards covering the proportionately high initial capital costs (e.g. infrastructure, new technology research) arising at the early development stage of emerging strategic industries with significant futures based on the expectation of substantial long-term returns on this state investment for the economy and public welfare (Lall 2003; Rodrik 2004, 2007; Schmitz 2007). The theory has had a particularly strong influence on development thinking in China and other East Asian states, as clearly demonstrated in their macro-development plans in which fostering emerging strategic industries constitutes a core programmatic element. Where the government seeks more direct involvement in strategic industry development it will form new or encourage existing state-owned enterprises (SOEs) to play an active part in meeting plan objectives. In addition, the government will look to develop close relationships with business enterprises generally through using a comprehensive range of policy mechanisms. Ecological modernisation also highlights the importance of state policies and institutions in helping markets and paths of economic development evolve towards more environmentally friendly outcomes.

\subsection{China's Renewable Energy Development}




\subsubsection{Power Generation and Energy Production Overview}

As Table 1 shows, hydropower has clearly dominated China's renewable energy development over time, this being broadly consistent though with international norms. The government has targets to increase power capacity levels in this essentially state-run industry to $325 \mathrm{GW}$ by 2015 under the $12^{\text {th }}$ Five-Year Plan, and then to $430 \mathrm{GW}$ by 2020 under its medium to long-term renewable energy strategy. This is primarily based on the further construction of large hydroelectric dams, the country's programme for which is the world's largest (IHA 2013). Meanwhile, China's installed wind energy capacity industry has expanded dramatically since the mid-2000s to reach $75.4 \mathrm{GW}$ by 2012 , and further rapid growth is planned in accordance to government targets. The country's fastest growing sector however is solar photovoltaic (PV), increasing over 100 -fold since 2006 to reach $8.3 \mathrm{GW}$ by 2012. China's biomass power generation sector has meanwhile experienced steady growth, rising to 8.0GW installed capacity by the same year. These four sectors hydropower, wind, solar PV and biomass - are responsible for virtually all the country's power generation from renewables. A further four sectors make an extremely minor contribution: geothermal is a relatively mature technology industry that has grown very slowly worldwide. Tidal energy and concentrating solar power are both still infant micro-sectors but with considerable potential for future market and industry growth. As earlier indicated, wave energy technology remains at the experimental stage with no installed capacity yet worldwide. Even in these very small sectors the Chinese government has set relatively ambitious targets for future development, as it has for all RE sectors (Table 1). Together, all renewable energy

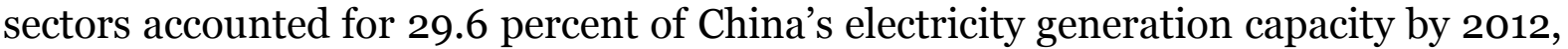
a share of the total that has gradually risen since the late 2000 .

National power generation capacity in total has increased almost 10-fold over the last two decades or so, from $126.6 \mathrm{GW}$ in 1990 to $1,150.5 \mathrm{GW}$ by 2012, and most of this can be attributed to a rapidly growing coal power sector. This contributed to 758.oGW (66.0 percent) of total generation capacity in 2012, three times that of hydropower, while the fast growing gas sector had reached $38.1 \mathrm{GW}$. Under the $12^{\text {th }}$ FYP period (2011-2015) is a programme to develop 16 large coal-power bases in the north and northwest provinces, where the bulk of China's coal deposits are situated, that will increase coal power capacity by 33 percent by 2015 (Yang and Cui 2012).

\subsubsection{Main Motive Factors for China}

There have been three main motives that have driven the expansion of renewable energy in China, the first being important environmental and welfare imperatives. High carbon economic activity is causing acute pollution and other environmental problems in the country, correspondingly leading to adverse social welfare effects. China overtook the United States in 2006 as the world's biggest carbon dioxide $\left(\mathrm{CO}_{2}\right)$ emitter. Latest available figures show that by 2009 China's annual $\mathrm{CO}_{2}$ emissions level was estimated at 7,687 million tonnes, around a quarter of the global total. This has been principally driven by the country's burgeoning demand for fossil fuel energy that is thought to have increased between five to six-fold since 1990 (Zhao and Yin 2011). Two key points should be made here. A significant degree of China's energy demand derives from the carbon-intensive manufacturing operations of foreign investor firms that have been relocated from their originating countries (mainly from 
Europe, Japan and North America), thus helping them reduce their own carbon emissions. This carbon-intensive activity hosted by China serves the world market: foreign invested enterprises account for around 60 to 70 percent of the country's exports. One could therefore argue that China's high carbon emission levels are as much a product of global capitalism as national economic development. Furthermore, China's energy demand is in a functional relationship with realising important domestic policy goals. Many communities in the nation's more remote interior provinces either have inadequate electricity supply or none at all. Strengthening the national grid in these areas is integral to achieving the Chinese government's overarching twin socio-economic objectives of closing income gaps within the country and lifting further hundreds of millions of its people out of poverty. The provision of key welfare services (health, education, utilities like freshwater supply) all depend on electricity supply, whether grid-connected or offgrid generated. In sum, China's power needs over the next few decades will be far greater than any other nation.

Rising fossil fuel consumption is nevertheless causing significant environmental and welfare degradation in China. The government's ambitious strategy for expanding coal-power capacity locks the country into a high emissions trajectory for decades to come, unless both clean coal and carbon capture and storage technologies make considerable advances in the future. Chinese cities are already among the world's most polluted. The China Council for International Cooperation on Environment and Development (CCICED 2012) reported that in the year 2000 almost 300 people per million population were dying in China due to high emission particulate levels, the world's highest rate, and this was expected to rise to almost 900 per million by 2030, placing the country even further ahead of other parts of the world. Many parts of China are also highly vulnerable to the climate change risks of extreme weather and rising sea-levels. The nation's burgeoning middle class is correspondingly becoming more politically vocal about quality of life issues, such as pollution abatement.

The second main motive behind China's push for renewables is energy security, which can be understood generally as addressing supply risk, price risk and environmental risk, this last aspect already discussed above. In relation to the first two risk types, sustained high growth rates in energy demand is rapidly depleting China's own fossil fuel deposits. It is the world's second largest oil and coal importer, and the fourth largest importer of liquefied natural gas (BP 2013, Yang and Cui 2012). Concerning nuclear, the country possesses only an estimated 1 percent of global uranium reserves, currently maintains a 65 percent import dependency on the mineral and has seen its uranium import levels triple from 2009 to 2011. Analysts expect China to overtake the US as the world's largest uranium importer by 2020 (Massot and Chen 2013). Although its energy import dependency ratio overall is not high by most international comparisons (9 percent in 2010) this is set to rise inexorably in the future, consequently making China more susceptible to the vicissitudes of foreign supply sources (Dent 2013). This is potentially further compounded by volatility in international prices for oil, gas and coal. Renewables have the advantage of being inherently indigenous energy sources, thus providing a long-term solution to foreign energy supply risk. Although some RE sectors are prone to occasional spikes in commodity price levels (e.g. polysilicon and solar PV cell manufacturing), they have been historically less exposed to price risk than fossil fuel sectors. The third main motive can be linked directly to strategic industry theory. Renewables are seen by China and most other countries as emerging strategic 
industries. The rationale for government support of their development was previously made.

\section{China's Renewable Energy Policies and Strategies}

\subsection{Renewables as part of a New Development Approach}

Renewable energy development in China cannot be considered in isolation of the broader development processes, strategies and contexts in which it is embedded. The government's more substantial promotion of renewable energy and national business growth of RE sectors over the last decade or so has occurred during a phase when China's leaders have adopted new approaches and thinking on national economic and social development generally (CCICED 2009a, 2009b, 2010, 2011, 2012; NDRC 2006; 2007b; 2011). Soon after assuming power, President $\mathrm{Hu}$ Jintao proclaimed the 'scientific development concept' would form the new ideological basis for China's future economic and social development, formally ratified into the national constitution at the $17^{\text {th }}$ Party Congress in October 2007. One of its core aims was to foster a resource-saving and environment-friendly 'harmonious society', and "developing the economy in a more balanced manner, paying less attention to gross domestic product (GDP) growth per se and more attention to such things as the ecological costs of the headlong rush for development" (Fewsmith 2008: 88). This new vision for China's development connected especially with the first identified motive (environmental and sustainable development imperatives) driving the promotion of renewable energy, and the government's five-year plans and associated strategic development programmes reflected this shift towards more qualitative development objectives.

The $11^{\text {th }}$ FYP (2006-2010) was the first to do so, and it was also during this time that ideas on ecological modernisation were beginning to influence Chinese policymakers. In the year 2007, three key inter-related events reflected new development thinking in China: the Chinese Academy of Sciences published its inaugural China Modernization Report 2007: Study on Ecological Modernization, and the government launched its first National Climate Change Strategy as well as its Medium and Long-Term Development Plan for Renewable Energy, also the first of its kind and that introduced a substantive strategic industry development programme for renewables. The convergence of ecological modernisation and strategic industry thinking was even more clearly evident in the overarching aims of the current $12^{\text {th }}$ FYP (2011-2015). As well as aiming to achieve more equitable income growth, promote domestic consumption, improve social infrastructures and strengthen China's innovatory capabilities, a prime focus of the $12^{\text {th }} \mathrm{FYP}$ was to promote lower carbon development (NDRC 2011). The stronger ecological modernisation approach to China's future development was re-affirmed at the $18^{\text {th }}$ Party Congress held in November 2012 when $\mathrm{Hu}$ Jintao announced the goal of building an 'ecological civilisation' and "achieve lasting and sustainable development of the Chinese nation" (address to the $18^{\text {th }}$ Party Congress, 8 November 2012).

\subsection{Is China's Approach to Renewable Energy Development Different?}


By early 2013, 127 countries worldwide had introduced RE policy support mechanisms (up from just 55 countries in 2005) and 138 countries had set defined renewable energy targets. RE policy instruments come in various forms but may be generally categorised as follows:

- Regulatory mandates: establishing legally binding requirements on firms to undertake particular action, such as renewable portfolio standards.

- Direct financial support: such as state subsidies, grants, loans, and capital investment in RE sector plants and infrastructure.

- Market-based instruments: adapting or using the market mechanism to provide a variety of different financial incentive measures, for example tax incentives, feed-in tariff systems, competitive bidding, and tradable permits.

Considerable convergence has occurred internationally around the utilisation of similar policy instruments, such as feed-in tariffs (FiT) where the government offers price-based incentives to individuals and companies to install and operate renewable energy equipment. By early 2013, 71 countries and 28 sub-national states around the world had enacted FiT legislation, where in China it has proved a significant spur to business growth and investment in renewables from small to larger scale installations. China is also among the 22 countries to have introduced renewable portfolio standard (RPS) that mandate energy suppliers to source minimum quota levels of electricity generation from renewable energy systems.

Developed economies and larger emerging economies, such as China, tend to have comprehensive RE policies that include a mix of regulatory mandate, direct financial support and market-based mechanisms. The application and balance of these will depend on the development stage of the renewable energy sector in question and the prevailing political economy of the country. Generally speaking, market-liberal country governments unsurprisingly have a special predilection for market-based instruments whereas more state-directed economy governments have more frequently deployed direct financial support policies. The latter is not just relevant to China but also many other East Asian economies with strong state capacity traditions (e.g. South Korea, Malaysia) and where SOEs play an important role in the energy sector. East Asian states have additionally demonstrated a proclivity for substantive strategic long-term planning on renewable energy development, this being arguably more evident in the region than any other (Dent 2012). What makes China most notably different, though, from all other countries is the absolute scale on which its policies, strategies and investment (both public and private) is facilitating renewable energy development, particularly regarding installed capacity and equipment manufacture, and in the prospective future on efficiency performance and technoinnovation. The relationship between government and business in China's RE industries is also rather uniquely complex due to the sheer density of state and corporate actors, the burgeoning expansion of business activity and issues of policy co-ordination involving multiple state agencies.

China's hydropower policies date back many decades but it was not until the $1990 \mathrm{~s}$ that the government started to pursue a multi-sector renewable energy policy. The 1995 China Electric Power Act was the country's first legislation to call for the promotion of renewables generally. This was soon followed by the first specific RE 
policy landmark with full legal status, the 1996 Brightness Programme, located in the $9^{\text {th }}$ FYP (1996-2000) and based on approximately US $\$ 1.2$ billion public investment to install hydropower, solar PV and wind energy facilities in over 1,00o townships and villages in rural communities. Soon thereafter a series of direct financial support measures were introduced in the $10^{\text {th }}$ FYP (2001-2005) period. The $10^{\text {th }}$ FYP proclaimed that production capacities in the wind, solar and geothermal energy sectors should be increased but did not set specific development targets (NDRC 2001, NREL 2004). These came later when renewables became priority emerging strategic industries. The 2003 Wind Power Concession Programme included plans to create up 20 large wind farms of 100-200MW capacity and the National Development and Reform Commission (NDRC) correspondingly set China's first national target of reaching $20 \mathrm{GW}$ of wind energy capacity by 2020.

The introduction of the Renewable Energy Law (REL) in 2006 at the eve of the $11^{\text {th }}$ FYP proved critical to expanding and diversifying renewables development. It created a far more robust legislative basis for business investment and established national standards for RE technologies and production (NEB 2008). This was complemented by the Medium and Long-Term Development Plan for Renewable Energy, implemented from September 2007. The Plan set out China's ambitious targets for multi-sector renewable energy development to 2020 and backed up with US $\$ 263$ billion of public investment. Even greater government stimulus was provided in the $12^{\text {th }}$ FYP (2011-2015) that included a RMB4 trillion (US\$610 billion) funded programme to promote seven Strategic Emerging Industries (SEI) for 'clean' development and a 'new industry base', namely: new energy, new generation ICT, energy-saving and environment protection, biotechnology, high-end equipment, new materials and alternative energy cars. Renewables are specified as a key component of the 'new energy' SEI sector that in addition included nuclear power. Under the SEI programme, China plans to enhance its new technological and innovation capabilities in wind energy and solar PV as part of a broader strategy of transforming China from a 'world factory' into an 'innovative hub' economy. The 2012 Energy Policy White Paper reaffirmed the government's commitment to vigorously develop renewables as "a key strategic measure for promoting the multiple and clean development of energy, and fostering emerging industries of strategic importance" (State Council of China 2012: 11).

In the $12^{\text {th }}$ FYP period to date, China's renewable energy policy has intensified with an increasing number of initiatives and regulations introduced in order to keep pace with business and industry growth, and deal with challenges arising from it (CNREC 2013). These include problems arising with gaps in grid connectivity and other infrastructural bottlenecks, establishing up-to-date technical standards, coordinating central and local government policy concerning regional RE business development, and establishing clearer demarcations of responsibility among various actors in different renewable energy systems. It is beyond the scope of this study to explore these issues in great detail but some will be examined in discussions that follow on state-business relationships in China's RE industries. 


\section{Implications}

\subsection{Overview}

From the early 2000 s to early 2010s, China has made the transition from being a net importer of renewable energy products to the world's largest manufacturer and exporter of them, and the largest investor in RE plant development. In addition to its dominant position in the global hydropower industry, the country now produces around two-thirds of solar PV equipment (up from just 5 percent in 2004), fourfifths of solar water heaters and almost half of wind turbines worldwide (EPIA 2013, REN21 2013, GWEC 2013). The burgeoning growth of national RE production and installed generation capacity has been driven by rising public and private sector investment. In 2005, China invested US $\$ 5.8$ billion in renewable energy rising to US $\$ 66.6$ billion by 2012, almost twice that for the United States (US $\$ 36.4$ billion) and not far behind Europe's combined figure of US\$79.9 billion (REN21 2013). China's state-owned enterprises play a very active role in national renewable energy development. These can be generally categorised as large-scale central government administered corporations or smaller local government-owned companies serving the energy needs of city municipalities and individual provinces. Examples of the former include the two state-owned grid companies that monopolise China's electricity grids, the government's five power generation companies (e.g. Guodian, Huadian) and national energy companies, e.g. Sinopec and SinoHydro. Naturally, both SOE types have close relationships with governing state agencies responsible for central and local government RE policy, although they can exercise high degrees of corporate autonomy and moreover compete among each other. Just as renewable energy sectors vary significantly from each other, so there are there many differences in the types of enterprises and markets that exist across them. Broadly speaking, an energy industry value-chain can be divided into the following elements, upstream to downstream:

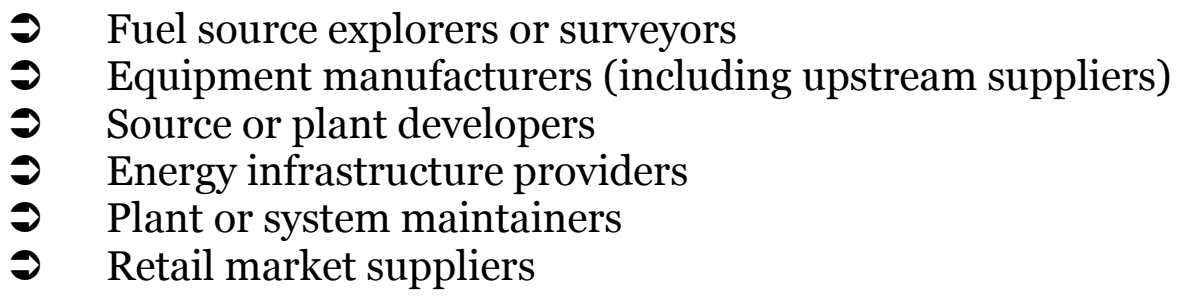

\begin{tabular}{|c|c|c|c|c|c|c|}
\hline & Coal, Oil, Gas & Nuclear & Hydropower & Wind & Solar PV & Biomass \\
\hline Fuel source explorers or surveyors & Public & Public & Public & Public / Private & Public/ Private & Public / Private \\
\hline $\begin{array}{l}\text { Equipment manufacturers (plus } \\
\text { upstream suppliers) }\end{array}$ & Public / Private & Public / Private & Public / Private & Private & Private & Private \\
\hline Source or plant developers & Public & Public & Public & Public & Public / Private & Public \\
\hline Energy infrastructure providers & Public & Public & Public & Public & Public & Public \\
\hline Plant or system maintainers & Public & Public & Public & Public & Public/ Private & Public / Private \\
\hline Retail market suppliers & Public & Public & Public & Public & $\begin{array}{l}\text { Public, n/a } \\
\text { prosumers }\end{array}$ & Public \\
\hline
\end{tabular}


Table 2 provides a comparative overview of how these differ across fossil fuel, nuclear and renewable energy sectors, also indicating the mix of Chinese public and private sector enterprises that exist in each part of the matrix. As indicated, SOEs dominate along the whole value-chain of China's 'incumbent' fossil fuel, nuclear and hydropower sectors and many RE industry aspects. Li (2013) reports that by 2011 there were some 700 SOEs involved for example in wind farm plant development. The country's five government power generation companies alone were responsible for installing 57.0 percent of wind energy generation and local SOEs another 22.4 percent. This contrasted with just 4.6 percent for China's private wind farm developers, 1.3 percent for foreign firms and 14.7 percent for foreign joint venture projects. A similar situation exists at the plant development level in the biomass power generation industry. However, the solar PV industry is different due to its highly 'distributed' nature (i.e. multitudinous building-integrated installations) that has allowed a growing number of private sector firms over time to enter various aspects of the value-chain. The wider deployment of micro-scale RE technology applications generally - roof-top PV, small wind turbines, biomass boilers, picohydro devices, etc - has created 'prosumer' individuals and organisations (including firms) that both produce and consume their own generated electricity and thermal power by and large independently, thus diminishing the need for energy supply companies. However despite the rapid growth of PV prosumers in China, utility-scale solar park capacity has grown even faster and is now presenting opportunities for energy SOEs to become market players here also (IEA 2013). In general, the country's established energy SOEs with roots in fossil fuels, nuclear and hydropower have simply diversified into wind, solar, biomass and other renewables by applying their economies of scope advantages of existing technical expertise and assets to these new emerging power sectors. China's public and private sector enterprises have in addition become more vertically integrated up and down industry value-chains. Below are some illustrative examples of the above points:

- Deploying its marine engineering expertise, national oil company CNOOC has developed offshore wind projects, as well on onshore wind farms, biomass generation plants and biofuel production. Other major state-owned oil companies, Sinopec and CNPC, have too become scaled up biofuel producers.

- Hydropower SOEs SinoHydro Group, and HydroChina Corporation and China Three Gorges Corporation have engaged in wind farm development, the latter two enterprises in overseas projects, e.g. in Pakistan. Shenhua Group, the world's largest coal company, and China Guangdong Nuclear Power are also among China's major wind farm developers.

- China's largest wind farm developer is Longyuan Power Group, a subsidiary of power generation SOE China Guodian Corporation. Longyuan is also involved in developing solar, biomass, geothermal and tidal energy projects.

$\rightarrow$ Sinovel, originally an SOE then turned private enterprise from 2011, is China's largest wind turbine manufacturer and additionally has operations in windfield design and planning, equipment transportation and installation, plant maintenance and remote data analysis services.

○ In June 2013 private wind turbine manufacturer Mingyang Wind Power formed a joint venture with state-owned China National Nuclear Corporation to develop wind farm projects in Henan province.

- Hong Kong based GCL Poly, the world's largest producer of polysilicon, the base material for mainstream solar PV cells, has recently ventured 
downstream into wafer manufacture, and is also developing the $300 \mathrm{MW}$ Datong solar park that when constructed will be the world's largest.

In many other countries, fossil fuel companies are also major players in developing clean energy systems. However, it is the scale on which this business diversification is occurring in China's energy companies that is somewhat exceptional. Their evolutionary transformation of into eventually green energy businesses, if this indeed transpires, is likely to prove a very slow process through gradual adaptations in response to changing technological, market and policy conditions. Yet this is consistent with the ecological modernisation approach. Government regulatory mandates will in the meantime require Chinese companies to source more power generation from renewables. In general the country's larger incumbent, and mainly SOE companies have most successfully diversified and thrived in most aspects of China's RE industry primarily due to economies of scale and scope advantages, and being well positioned to benefit from state support due to close connections with government ministries. There are additionally some interesting market dynamics at play. For instance, wind power generators rarely compete against coal-power generators as they are invariably the same companies. There exists intra-company competition between old and new energy divisions, China's hydropower companies may take a competitive position against their fossil fuel rivals, and the country's five large state-owned power generating companies compete against their local-level counterparts, but as they are all SOEs this may be considered an intra-state competition of sorts.

Indeed, intra-state competition and tensions have had a profound impact on China's renewable energy business on various levels, this proceeding from governance and co-ordination challenges involving central government, local government, SOEs and private companies. On the retail side, competing SOEs provide the main bulk of electricity sold to consumers (Table 2) at prices regulated locally but in accordance to centralised NDRC guidelines, yet a significant lack of transparency persists on both price formulation and the allocation of retail market contracts among enterprises (Lin and Purra 2012). Furthermore, as Shi (2013: 8) observed that local governments in China were often encouraging the development of RE plants to help meet their economic growth targets, more specifically arguing that: "The construction of power plants is mainly for increasing GDP rather than meeting the demands for electrical power, leading to serious blind construction of power plants in various areas". Applying this to the wind energy industry, plant developer companies such as Longyuan have built numerous wind farms that may take a considerably long time before they are connected to the grid, explaining why by the early 2010 s an estimated fifth of China's wind power installations were in effect dormant. Contestations over grid connectivity and market demarcations among mainly power generation SOEs, grid infrastructure SOEs, local energy SOEs, local government and central government has created a difficult business environment in many aspects of this industry (GWEC 2013, Li 2013), and to some extent in the smaller solar PV power generation sector (CPIA 2013). Notwithstanding these problems, these industries continue to demonstrate robust growth.

Table 2 shows that the only element of the value-chain where the private sector dominates in China's RE industries (except hydropower) is in equipment manufacture. Wind energy companies such as Goldwind, Sinovel, Mingyang, United Power and Dongfang have all become key global players in their industry, as have 
Yingli, JA Solar, Suntech and Trina in the PV sector. Although some of these firms once had SOE origins (e.g. Sinovel, Goldwind), the rapid expansion of this valuechain element is a critically important part of China's renewable energy development story. In 2004, the country had just six wind turbine firms, rising to 40 by 2007 and to around 90 by 2011 ( $\mathrm{Li}$ 2013). Best estimates suggest over 400 solar PV manufacturers now operate in China (IEA 2013). There has been a dynamic entrepreneurial response generally from the nation's public and private business sectors to the government's strengthening policy support and ambitious strategic planning on renewables. However, the rapidly increasing number of RE equipment producers has created overcapacity problems in wind and solar PV most notably, this also having a significant global impact. Despite that in 2012 alone around 50 solar PV manufacturers filed for bankruptcy in China - five times the number of their European rivals - the country continued to expand PV production capacity (9.5 percent growth in module output in 2012) as surviving companies take a positive view on long-term market growth and strong government support for the sector (CPIA 2013).

Most recently, the government has incentivised the growth of domestic PV installations after the sharp fall in Western market demand, and state-owned banks have also provided assistance during these upheavals, for instance lending the nation's top ten PV firms a combined US $\$ 20$ billion in 2012 (REN21 2013). Current structural changes are likely to make China's solar PV manufacturing industry far more concentrated as small-scale producers either go bust or are taken over, and SOEs also extend their interests into this value-chain element (Solidiance 2013). We may additionally expect greater further vertical integration in China's wind and solar PV sectors as enterprises seek to diversify and consolidate their competitive positions. Here we see a convergence of interest between the Chinese government and energy companies towards achieving yet greater scale advantages in both power generation and equipment manufacture, making China even more price competitive in international markets.

Western criticism of the Chinese government's strategic industry support of its RE enterprises has led to intensifying trade disputes over solar PV equipment and wind turbines in particular. On the other hand, downstream firms in these industries worldwide (e.g. installation and maintenance companies) have welcomed China's mass production of affordable renewable energy goods, and have lobbied against the application of US and EU trade restrictions on Chinese imports. Whatever transpires on the trade diplomacy front, China's government and companies share a similar strategic vision of strengthening domestic techno-innovatory capacity in renewable energy industries. This is consistent with the $12^{\text {th }}$ FYP's core development objective of transforming the country into an 'innovative hub' economy, and Chinese company strategies of competing increasingly on technological terms and not just price.

\section{Conclusions}

The environmental and welfare costs of China's high carbon activity are mounting. In acknowledgment of this, the government has endeavoured to establish a new development approach influenced by ecological modernisation thinking that seeks to reconcile these core objectives. This has combined with strategic industry theory 
ideas on state proactivity on supporting the development of renewables as key emerging industries of the future. Over time, the Chinese government has gradually strengthened its renewable energy policies and strategies that are in turn embedded in larger policies and strategies that aim to foster greener, cleaner economic and business development. It has been shown how various types of state-owned enterprises (SOEs) still dominate most aspects of China's renewable energy industries. This has made it often difficult to identify where the demarcations of state and business lie. One could make a case for considering SOEs themselves as a form of policy instrument, or at least an extension of China's RE policy. Yet intense business competition also exists among these public enterprises. Overall, China's renewable energy business landscape is highly complex, and can be generally characterised by dynamic public and private sector entrepreneurism, strong intersectoral connections that extend to fossil fuel and nuclear power industries, a dense mix of SOEs and private companies, intensifying business competition at multiple levels, and fast expanding production capacity based on optimistic expectations on future industry growth.

Notwithstanding the country's notable achievements on renewable energy development to date, both the Chinese government and business face some difficult challenges ahead. We have only been able to touch upon those facing policy-makers in particular, namely grid connectivity problems and other infrastructural bottlenecks, establishing up-to-date technical standards, co-ordinating central and local government policy concerning regional $\mathrm{RE}$ business development, and establishing clearer demarcations of responsibility among various actors in different renewable energy systems. The government's future targets on renewables development may look impressive in absolute terms (e.g. 430GW hydropower and $200 \mathrm{GW}$ wind by 2020) by direct international comparison. However, given that the country's energy system is growing fast on most fronts, the real challenge will be to raise renewables' relative share of national energy generation and consumption. Many nations have set the goal of renewables contributing around 15 to 30 percent of the nation's total electricity generation or total energy mix by 2020 (REN21 2013). China's present targets on electricity generation from non-hydro renewables especially are not that remarkable by comparison. For Chinese business in the international market context, the two main challenges will be how to address the protectionism of foreign trade partners and to improve domestic techno-innovatory capacity. The first of these challenges will naturally depend largely on factors beyond Chinese company control, specifically how foreign firms and governments respond to the perceived competitive threats China's RE industries pose. Regarding the second, with strong state support aimed at transforming the country into an 'innovation hub' economy - for example through the $12^{\text {th }}$ Five Year Plan's Strategic Emerging Industries programme - backed by considerable levels of domestic business investment, Chinese companies are already making significant advances on technoinnovation in wind, solar and other RE sectors. This represents another area where China can make increasingly important contributions to global renewable energy development in the future.

Christopher M. Dent is Professor of East Asia's International Political Economy, East Asian Studies, University of Leeds. He has acted as a consultant advisor to the British, Australian, Chilean, 
German and United States Governments, as well as the Asian Development Bank, European Commission, ASEAN Secretariat and APEC Secretariat.

\section{References}

BP (2013) Statistical Review of World Energy 2012, London: BP.

China Photovoltaic Industry Alliance / CPIA (2013) Annual Report of China PV Industry 2012, Beijing: CPIA.

China Council for International Cooperation on Environment and Development / CCICED (2009a) China's Pathway towards a Low Carbon Economy, Beijing: CCICED.

-- (2009b) China’s Green Prosperity Future: Environment, Energy and Economy, Beijing: CCICED.

-- (2010) Annual Policy Report 2009, Beijing: CCICED.

-- (2011) China's Low Carbon Industrialization Strategy, Beijing: CCICED.

-- (2012) Annual Policy Report 2011, Beijing: CCICED.

China National Renewable Energy Centre / CNREC (2013) Renewable Energy in China Database, Beijing: CNREC.

Christoff, P. (1996) ‘Ecological Modernisation, Ecological Modernities’, Environmental Politics, Vol 5(3), pp 476-500.

Dent, C.M. (2012) 'Renewable Energy and East Asia's New Developmentalism: Towards a Low Carbon Future?', (2012), The Pacific Review, Vol 25(5), pp 561-587.

-- (2013) 'Understanding the Energy Diplomacies of East Asian States', Modern Asian Studies, Vol 47(3), pp 935-967.

European Photovoltaic Industry Association / EPIA (2013) Global Market Outlook for Photovoltaics 2013-2017, Brussels: EPIA.

Fewsmith, J. (2008) 'China in 2007: The Politics of Leadership Transition', Asian Survey, Vol 48(1), pp 82-96.

Global Wind Energy Council / GWEC (2013) Global Wind Report: Annual Market Update 2012, Brussels: GWEC Secretariat.

Huber, J. (1982) Die Verlorene Unschuld der Okologie, Frankfurt am Main: Fischer Verlag.

International Energy Agency / IEA (2013) National Survey Report of PV Power Applications in China, 2012, Paris: IEA. 
International Hydropower Association / IHA (2013) IHA Hydropower Report 2013, London: IHA.

Jänicke, M. (1984) Umweltpolitische Pravention als Okologische Modernisierung und Strukturpolitik, Berlin: Wissenschaftszentrum.

Jänicke, M. (1988) 'Okologische Modernisierung: Optionen und Restriktionen Praventiver Umweltpolitik', in U. Simonis (ed.) Praventive Umweltpolitik, Frankfurt am Main: Campus.

Lall, S. (2003) 'Reinventing Industrial Strategy: The Role of Government Policy in Building Industrial Competitiveness', QEH Working Paper Series, No. 111, Oxford: Queen Elizabeth House.

Langhelle, O. (2000) 'Why Ecological Modernization and Sustainable Development Should not be Conflated', Journal of Environmental Policy and Planning Vol 2(4), pp 303-322.

Li, J. (2013) China's Wind Energy Outlook 2012, Brussels: Global Wind Energy Council.

Lin, K.C. and Purra, M.M. (2012) 'Transforming China's Electricity Sector: Institutional Change and Regulation in the Reform Era', Centre for Rising Powers Working Paper Series, No. 8, Cambridge: CRP.

Massot, P. and Chen, Z.M. (2013) 'China and the Global Uranium Market: Prospects for Peaceful Coexistence', The Scientific World Journal, Vol (2013), Article ID 672060 (open access), 11 pages.

National Development and Reform Commission / NDRC (2001) China's $10^{\text {th }}$ FiveYear Plan for Economic and Social Development, Beijing: NDRC.

-- (2006) China's $11^{\text {th }}$ Five-Year Plan for Economic and Social Development, Beijing: NDRC.

-- (2007a) Medium and Long-Term Development Plan for Renewable Energy in China, Beijing: NDRC.

-- (2007b) China's National Climate Change Programme, Beijing: NDRC.

-- (2011) China's $12^{\text {th }}$ Five-Year Plan for Economic and Social Development, Beijing: NDRC.

National Energy Bureau / NEB (2008) China's Renewable Energy: Development Overview 2008, Beijing: NEB.

National Renewable Energy Laboratory / NREL (2004) Renewable Energy in China, Washington DC: NREL.

REN21 (2006) Renewables 2005 Global Status Report, Paris: REN21 Secretariat. 
-- (2013) Renewables 2012 Global Status Report, Paris: REN21 Secretariat.

Rodrik, D. (2004) 'Industrial Policy for the Twenty-First Century', KSG Working Paper Series, No. RWP04-047, Cambridge, MA: Kennedy School of Government.

Rodrik, D. (2007) 'Normalizing Industrial Policy', paper prepared for the Commission on Growth and Development, Harvard University, September 2007.

Schmitz, H. (2007) 'Reducing Complexity in the Industrial Policy Debate', Development Policy Review, 25(4): 417-428.

Shi, L. (2013) 'Removing System Barriers, Ensuring the Large Scale Wind Energy Development', China Renewable Energy, Vol 2(1), pp 4-9.

Solidiance (2013) China's Renewable Energy Sector: An Overview of Key Growth Sectors, Shanghai: Solidiance.

State Council, China (2012) China's Energy Policy White Paper 2012, Beijing: State Council.

Weale, A. (1992) The New Politics of Pollution, Manchester: Manchester University Press.

Yang, A. and Cui, Y. (2012) Global Coal Risk Assessment: Data Analysis and Market Research, Washington DC: World Resources Institute.

York, R. and Rosa, E. (2003) 'Key Challenges to Ecological Modernization Theory', Organization and Environment, Vol 16(3), pp 273-287.

Zhao, X. and Yin, H. (2011) 'Industrial Relocation and Energy Consumption: Evidence from China', Energy Policy, Vol 39, pp 2944-56. 